\title{
PEMETAAN KAPASITAS PESANTREN DI KABUPATEN MAROS PROVINSI SULAWESI SELATAN
}

\author{
MAPPING THE CAPACITY OF PESANTREN \\ IN THE DISTRICT MAROS OF SOUTH SULAWESI PROVINCE
}

\author{
Rosdiana \\ Balai Penelitian dan Pengembangan Agama Makassar \\ Jl. A.P.Pettarani No.72 Makassar \\ Email: rosdianalitbang03@gmail.com
}

Naskah diterima tanggal 12 Mei 2016 naskah direvisi tanggal 20 Mei 2016. Naskah diterima tanggal 3 Juni 2016.

\begin{abstract}
Abstrak
Penelitian ini berupaya untuk memetakan persebaran pesantren, kapasitas yang dimiliki pesantren serta pengembangan pemberdayaan yang diprogramkan pesantren di Kabupaten Maros. Penelitian merupakan penelitian pemetaan untuk melihat kondisi ril pesantren dengan mendeskripsikan, menggambar peta dari kapasitas pesantren di Kabupaten Maros. Hasil penelitian menunjukkan bahwa terdapat 22 pesantren di Kabupaten Maros yang tersebar di sebelas kecamatan. Kapasaitas pesantren diukur berdasarkan lima komponen pesantren seperti ketersediaan kiai, asrama, masjid, dan pembelajaran kitab serta pemberdayaan. Kelima komponen tersebut belum sepenuhnya dimiliki oleh sebagian pesantren, namun eksistensi dari pesantren tersebut tetap menampakkan diri dalam hal turut serta mencerdaskan santri dengan ciri yang melekat pada masing-masing pesantren. Program pemberdayaan santri yang ditetapkan oleh pesantren terlihat dari keberlanjutan sebagian tidak berjalan dan pengelolaannya belum begitu terfokus terutama dalam melibatkan santri dalam pengelolaannya.

Kata Kunci: kapasitas, pesantren, santri, pemberdayaan.
\end{abstract}

\begin{abstract}
This study aims to map the distribution of schools, the capacity of schools and the development of empowerment of pesantren's programme in Maros. The research is a research mapping to see the real condition of schools by describing, drawing maps of the capacity of schools in Maros. The results showed that there are 22 schools in Maros spread over eleven districts. Capacities boarding schools are measured based on five components such as the availability of kiai, dormitories, mosques, and learning books and empowerment. The five component are not wholly owned by some schools, but the existence of these schools still manifest themselves in terms of educating students participated with the characteristics inherent in their respective schools. The programme of santri(students) empowerment implemented by the pesantren, it seemed that its sustainable development was partially not running and the pesantren did not too focus especially on the involvement students in its management
\end{abstract}

Keywords: capacity, schools, students, empowerment

\section{PENDAHULUAN}

$\mathrm{P}$ andangan kesejarahan menujukkan bahwa kehadiran pesantren di negeri ini seiring dengan proses penyebaran agama Islam yang untuk pertama kalinya dilakukan atau dibawa kepemimpinan para wali. Awalnya, pesantren merupakan pusat-pusat penyebaran Islam oleh para wali yang merupakan sambungan sistem zawiyah. Sistem zawiyah adalah sistem pembelajaran atau trasmisi keilmuan mula-mula diselenggarakan di dalam masjid secara berkelompok berdasarkan diversifikasi aliran sehingga pada tataran selanjutnya mengkristal menjadi aliran-aliran pemikiran agama (schools of thought) (Bawani, 2011:45).

Pesantren adalah lembaga yang bisa dikatakan merupakan wujud proses wajar perkembangan sistem pendidikan nasional. Dari segi historis pesantren tidak hanya identik dengan makna keislaman, tetapi juga mengandung makna keaslian Indonesia (indigenous) (Madjid, tth: 3). Menurut Octavia (2014: xi) pesantren merupakan lembaga pendidikan yan genuine dan tertua di Indonesia. 
Eksistensinya sudah terujui oleh zaman, sehingga sampai saat ini masih survive dengan berbagai macam dinamikanya. Zakaria mengemukkan institusi ini (pondok pesantren) berperan sebagai wadah untuk mendalami ilmu agama, memelihara tradisi keislaman, melanjutkan ulama, dan pemimpin umat (2010: 45). Hal senada diungkapkan oleh Suhardi (2012: 316) sekolah berbasis pesantren mempunyai peran yang signifikan dalam upaya membentuk peserta didik yang berjiwa religious, akhlakul hasanah, disiplin, sederhana, menghormati orang yang lebih tua, dan memahami filosofi kehidupan.

Pesantren sebagai komunitas dan sebagai lembaga pendidikan yang besar dan luas penyebarannya diberbagai pelosok tanah air telah banyak memberikan saham dalam pembentukan manusia Indoensia yang religious. Lembaga tersebut telah melahirkan banyak pemimpin bangsa di masa lalu, kini, dan agaknya juga di masa datnag. Lulusan pesantren banyak yang mengambil partisipasi aktif dalam pembangunan bangsa (Tafsir, 2013: 290).

Pesantren berkembang terus sambil menghadapi rintangan demi rintangan. Sikap ini bukan ofensif, melainkan lebih dari defensif; hanya untuk menyelamatkan kehidupannya dan keberlangsungan dakwah islamiyah. Pesantren tidak pernah memulai konfrontasi sebab orientasi utamanya adalah melancarkan dakwah dan menanamkan pendidikan. Pada tahap berikutnya, pesantren diterima masyarakat sebagai upaya mencerdaskan, meningkatkan kedamaian dan membantu sosio-psikis bagi mereka. Tidak mengherankan jika pesantren kemudian menjadi kebanggaan masyarakat sekitarnya (Qomar, tth: 11).

Pesantren yang telah mejadi bagian dari edukasi mendorong perkembangan jangkaun corak dan ragamnya, sehingga tidak lagi berbasis pedesaan dan pengajian kitab semata, tetapi telah menyebar di bebrbagai wilayah dengan corak ragam yang bervariasi. Keragaman itu menjadi dasar dalam mentipologi pesantren. Realitas ini menjadi amatan dalam pemetaan pesantren.

Penelitian tentang pesantren telah banyak dilakukan orang, tetapi penelitian pemetaan pesantren masih jarang dilakukan, apalagi pemetaan tentang, kapasitas pesantren terutama di wilayah timur Indonesia.

Penelitian pemetaan kapasitas pesantren yang dilakukan di Kabupaten Maros, diorientasikan pada tiga aspek, yaitu: persebaran pesantren beserta corak dan ragamnya serta jangkauan aksesibilitasnya; kajian difokuskan pada substansi pesantren berkaitan pilar utama pesantren seperti kiai/ustaz, santri/siswa, kitab/bahan ajar, masjid/mushallah/ tempat ibadah, pondok/asrama, termasuk sarana prasarana lainnya, dan program pengembangan dan aspek-aspek pendukung lainnya.

Pesantren dalam perspektif pendidikan Islam Indonesia adalah salah satu dari satuan pendidikan Islam yang dihadirkan untuk membina umat. Kehadiran awalnya yang berbasis pedesaan, dalam perkembangannya belum mampu mengakses pendidikan keagamaan terhadap sebagian besar umat Islam di pedesaan.

Berdasarkan latar belakang tersebut, maka permasalahan yang diangkat adalah bagaimana persebaran pesantren di Kabupaten Maros, bagaimana gambaran kapasitas yang dimiliki pesantren dan bagaimana pengembangan pemberdayaan yang dilakukan pesantren di Kabupaten Maros. Tujuan penelitian ini untuk memetakan pesersebaran pesantren di Kabupaten Maros, untuk mengetahui kapasitas yang dimiliki pesantren yang diteliti sehingga memudahkan dalam menentukan kebijakan pengembangannya, dan untuk mengetahui pengembangan pemberdayaan pesantren di Kabupaten Maros.

Penelitian diharapkan berguna bagi: pengelola pesantren dalam mengembangkan pesantren yang dikelolanya agar memiliki daya saing terhadap lembaga pendidikan lainnya. Instansi dan lembagan terkait dalam menyusun program pengembangan pesantren sebagai bagian dari penguatan potensi dan peran pesantren. Para peneliti untuk mengkaji pesantren dalam berbagai aspeknya secara lebih mendalam.

\section{Tinjauan Pustaka}

Pemetaan dalam Kamus Besar Umum Bahasa Indonesia, kata pemetaan, berasal dari kata dasar peta yang mendapat imbuhan sisipan "em" dan akhiran "an". Kata peta berarti gambar atau lukisan pada kertas dan sebagainya yang menunjukkan letak tanah, laut, sungai, gunung, dan sebagainya. Pemetaan adalah proses, cara pembuatan, membuat peta (2005: 867).

Kapasitas. Kata kapasitas adalah kata jadian dari bahasa Inggris capacity yang berarti, terisi penuh penurut kapasitasnya (Echols, 2000:97). Selain itu, kapasitas adalah kemampuan yang dimiliki 
seseorang, organisasi, lembaga (termasuk pesantren) atau masyarakat agar dapat melaksanakan fungsi esensial, memecahkan masalah, dan mencapai tujuan. Juga memahami kebutuhan pengembangan dari dalam lingkungan yang lebih luas secara berkelanjutan (www.nu.online.go.org, diakses 12 Januari 2015).

Pesantren. Pengertian pondok pesantren terdapat berbagai variasi, di antaranya menurut Nasir (2010: 80) pondok pesantren adalah lembaga keagamaan, yang memberikan pendidikan dan pengajaran serta mengembangankan dan menyebarkan ilmu agama Islam.

Beberapa tipe pondok pesantren, dalam menyelenggarakan pendidikan dan pengajaran bagi para santrinya, secara garis besar dapat dikelompokkan ke dalam dua bentuk pondok pesantren, yakni 1) pondok pesantren salafiah yaitu yang menyelenggarakan pengajaran Alquran dan ilmu-ilmu agama Islam, serta kegiatan pendidikan dan pengajaran sebagaimana yang berlangsung sejak awal pertumbuhannya. 2) pondok pesantren khalafiah yaitu pondok pesantren yang selain menyelenggarakan kegiatan kepesantrenan, juga menyelenggarakan kegiatan pendidikan formal (sekolah dan madrasah) (Noor, 2006: 44). Tipologi itu kemudian berkembang menjadi 3 tipe, yakni selain 2 tipe pertama, terdapat tipe ke tiga dalam bentuk pondok pesantren kombinasi (gabungan Salafi dan Khalafi) (Badan Litbang dan Diklat Kemenag, 2012: 19).

Penelitian pemetaan merupakan penelitian yang berbasis pada penelitian goografis yang berupaya untuk menggambarkan secara visual obyek penelitian. Dalam disiplin ilmu geografi ada yang pendekatan penelitian yang berkembang akhir-akhir ini, yaitu Geografis Information Sistym (GIS). Sistem Informasi Geografis (bahasa Inggris: Geographic Information System disingkat GIS) adalah sistem informasi khusus yang mengelola data yang memiliki informasi spasial (bereferensi keruangan). Atau dalam arti yang lebih sempit, adalah sistem komputer yang memiliki kemampuan untuk membangun, menyimpan, mengelola dan menampilkan informasi berefrensi geografis, misalnya data yang diidentifikasi menurut lokasinya, dalam sebuah database.

Pemetaan digunakan dalam berbagai bidang. Maknanya bervariasi sesuai dengan konteks, dalam kartografi, membuat peta fitur bumi. Di kognitif psikologi dan ilmu kognitif, tentang hubungan antara domain sumber dan target domain atau hubungan antara unsur-unsur sumber dan target dalam analogi. Dalam genetika, pemetaan gen tentang posisi relatif dari gen dalam genom. Dalam ilmu komputer, dapat dihitung setiap fungsi, prosedur, atau meja, misalnya berkaitan kunci nilai dalam array asosiatif. Dalam bidang ilmu pengetahuan dan teknologi, pemetaan mengacu pada distribusi geografis dan konsentrasi komponen sistem penelitian.

Pada bidang pendidikan, penelitian pemetaan telah diterapkan dalam school mapping, yang menggambarkan secara rinci di permukaan suatu daerah tertentu mengenai keadaan sekolah serta hubungannya dengan jumlah anak usai sekolah, perkembangan permukiman penduduk, sosial ekonomi dan lingkungan dalam arti luas. Tujuan dari pemetaan sekolah antara lain menata jaringan sekolah, meningkatkan mutu pendidikan, dan perencanaan dalam menentukan sekolah. Pemetaan kapasitas pesantren adalah bagian dari mapping school. Karena itu, segala aspek yang terkait di dalamnya, akan dipertahankan eksistensinya.

\section{METODE PENELITIAN}

Jenis penelitian adalah penelitian pemetaan. Kondisi ril pesantren digambarkan berdasarkan lokasi penelitian dengan menggunakan peta kapasitas, bertujuan untuk mendeskripsikan dan menggambar peta dari kapasitas dari lembagalembaga (pesantren) dalam wilayah Kabupaten Maros.

Obyek penelitian didekati dengan disiplin Ilmu Kependidikan. Teori-teori edukasi yang relevan dengan obyek penelitian akan digunakan untuk mendekripsi, menganalisis, dan mengiterpretasi data. Komponen pesantren meliputi pendidik (kiai), santri, pondok, masjid, kitab akan dikaji dalam penelitian ini melalui metode mapping capacity.

Berdasarkan sumbernya data dibagi kepada data primer dan data sekunder. Data primer akan diperoleh dari pesantren yang menjadi sasaran penelitian. Tentunya yang dimaksudkan adalah kiai satuan pendidikan, guru, staf, dan siswa siswa. Sementara data sekunder akan diperoleh dari instasi penyedia data terkait, seperti Kantor Kementerian Agama setempat, baik tingkat provinsi maupun kota/kabupaten, BPS setempat, perpustakaan daerah, perguruan tinggi setempat, dan lain-lain. 
Instrumen penelitian terdiri atas tiga yaitu pedoman observasi, pedoman wawancara, dan cek list digunakan untuk menjaring data. Sementara pedoman wawancara digunakan untuk menjaring data kualitatif. Menurut Sugiono langkah-langkah yang digunakan dalam analisis adalah reduksi data, penyajian data dan verifikasi (2005: 92). Kegiatan analisis dapat dilakukan sejak pengumpulan data di lapangan sampai penulisan laporan hasil penelitian. Pada dasarnya pengolahan dan analisis data dilakukan dalam empat proses yaitu: input data, manajemen data, query dan analisis, penayangan grafis dan visualisasi.

\section{PEMBAHASAN}

\section{Persebaran Pesantren Di Kabupaten Maros}

Persebaran pesantren di Kabupaten Maros berdasarkan data dari Kementerian Agama tahun 2015, terdapat 22 pondok pesantren yang tersebar di 11 kecamatan. Persebaran pesantren ini belum merata di setiap kecamatan di Kabupaten Maros masih terdapat tiga kecamatan yang belum memiliki pesantren. Masing-masing pesantren tersebut berdasarkan kecamatan, alamat, dan tahun berdiri lihat tabel 1.

Tabel. 1

Persebaran Pesantren Di Kabupaten Maros

\begin{tabular}{lllcc} 
No. & \multicolumn{1}{c}{ Pesantren } & \multicolumn{1}{c}{ Alamat } & Kec. & $\begin{array}{c}\text { Tahun } \\
\text { Berdiri }\end{array}$ \\
1 & PP. Darul Istiqamah Maccopa & Jl. Poros Makassar Maros KM.25 & Mandai & 1991 \\
2 & PP. DDI Hasanuddin & Jl. Poros Makassar Maros Batangase & Mandai & 2002 \\
3 & PP. An Nas Az Zahrah & Jl. Rambutan BTN H. Banca M.25/9 & Mandai & 2011 \\
4 & PP. Darussalam Barandasi & Jl. Masjid Raya No.05 & Lau & 1997 \\
5 & PP. DDI Soreang & Jl.Samudra No.31 Sorean Maros & Lau & 2006 \\
6 & PP. Nahdlatul Ulum Soreang & Jl.Samudra No.19 & Lau & 2002 \\
7 & PP.Yadi Bontocina & Jl. Makmur Dg.Sitakka No.47 & Turikale & 1982 \\
8 & PP. DDI Alliritengae & Jl. Taqwa No & Turikale & 1986 \\
9 & PPTQ. Assa'adah & Jl. H. Bohari No.2 & Turikale & 1995 \\
10 & PP. Darul Muttaqin Maccopa & Jl. Garuda Maccopa & Turikale & 2006 \\
11 & PP. Manbaul Ulum Tompobalang & Jl. Poros Leang-leang & Bantimurung & 1989 \\
12 & PP. Darul Ulum Amessangeng & Jl. Amessangeng Baru No.10 & Bantimurung & 1989 \\
13 & PP. Miftahu Muin Tekolabbua & Jl. Tekolabbua & Maros Baru & 1994 \\
14 & PP. Ainussyamsi & Jl. Masembo No.80 & Maros Baru & 1993 \\
15 & PP. Al Irsyad Biringkaloro & Jl.Poros Maccopa Amarang KM.4 No.5 & Tanralili & 1994 \\
16 & PP. Profesi Wandaniyatillah & Dulang Kel. Borong & Tanralili & 2005 \\
17 & PP. Babul Jannah & Jl. Damai Boropandang & Marusu & 2006 \\
18 & PP. Nurul Ikhwan Matana & Dusun Matana & Marusu & 2009 \\
19 & PP. Raudhaturrasyidin & Cambalangi Desa Tupabbiring & Bontoa & 2003 \\
20 & PP.Hj. Haniah & Jl.H.Bohari Dsn. Banyo Ds.Bontotallasa & Simbang & 2006 \\
21 & PP.Al Muhajirin DDI Sakeang & Jl. Tanag Dg. Tempo & Tompobulu & 1971 \\
22 & PP. Darul Arqam & Jl. Poros Laiya Cenrana & Cenrana & 1989
\end{tabular}

Sumber Data: Kementerian Agama Kabupaten Maros 2015

Tipologi, Kepemilikan, Letak dan Jarak serta Pendidikan yang Selenggarakan Pesantren

Pesantren terus mengalami perkembangan baik tempat, bentuk, hingga substansi telah mengalami perubahan. Pesantren tidak lagi sesederhana seperti apa yang digambarkan, tetapi pesantren mengalami perubahan sesuai dengan pertumbuhan dan perkembangan zaman. Perubahan ini juga diperlihatkan pesantren di Kabupaten Maros khususnya terlihat dari perkembangan tipologi pesantren. Tipologi persantren yang terdapat di Kabupaten Maros berdasarkan data yang peroleh dari penelitian hanya terdapat dua tipologi pesantren yakni tipologi khalafiah dan tipologi kombinasi, lihat tabel 2 . 
Tabel 2. Tipologi Pesantren di Kabupaten Maros

\begin{tabular}{|c|c|c|c|c|c|}
\hline \multirow[b]{2}{*}{ NO } & \multirow{2}{*}{ NAMA PONDOK PESANTREN } & \multirow{2}{*}{$\begin{array}{l}\text { LETAK PESANTREN } \\
\text { BERDASARKAN } \\
\text { KECAMATAN }\end{array}$} & \multicolumn{3}{|c|}{ PESANTREN BERDASARKAN TYPOLOGI } \\
\hline & & & SALAFIYAH & KHALAFIYAH & KOMBINASI \\
\hline 1 & Darul Istiqamah Maccopa & Mandai & 0 & 0 & 1 \\
\hline 2 & DDI Hasanuddin & Mandai & o & o & 1 \\
\hline 3 & An Nas Az Zahrah & Mandai & 0 & 0 & 1 \\
\hline 4 & Darussalam Barandasi & LAU & 0 & 0 & 1 \\
\hline 5 & DDI Soreang & LAU & o & o & 1 \\
\hline 6 & Nahdlatu1 Ulum Soreang & LAU & 0 & 0 & 1 \\
\hline 7 & Yadi Bontocina & Turikale & 0 & 0 & 1 \\
\hline 8 & DDI Alliritengae & Turikale & o & o & 1 \\
\hline 9 & PPTQ. Assa'adah & Turikale & o & o & 1 \\
\hline 10 & Darul Muttaqin Maccopa & Turikale & 0 & 0 & 1 \\
\hline 11 & Manbaul Ulum Tompobalang & Bantimurung & 0 & 0 & 1 \\
\hline 12 & Darul Ulum Amessangeng & Bantimurung & 0 & 1 & 0 \\
\hline 13 & Miftahu Muin Tekolabbua & Maros Baru & 0 & 0 & 1 \\
\hline 14 & Ainussyamsi & Maros Baru & 0 & 1 & 0 \\
\hline 15 & Al Irsyad Biringkal oro & Tanralili & 0 & 0 & 1 \\
\hline 16 & Profesi Wandaniyatillah & Tanralili & 0 & 0 & 1 \\
\hline 17 & Babul Jannah & Marusu & 0 & 0 & 1 \\
\hline 18 & Nurul Ikhwan Matana & Marusu & 0 & 0 & 1 \\
\hline 19 & Raudhaturrasyidin & Bontoa & 0 & 0 & 1 \\
\hline 20 & Hj. Haniah & Simbang & 0 & 0 & 1 \\
\hline 21 & Al Muhajirin DDI Sakeang & Tompobulu & 0 & o & 1 \\
\hline 22 & Darul Arqam & Cenrana & 0 & o & 1 \\
\hline & JU MLAH & & $\mathbf{0}$ & 2 & 20 \\
\hline & PERSENTASE (\%) & & $\mathbf{0 \%}$ & $\mathbf{9} \%$ & $91 \%$ \\
\hline
\end{tabular}

Kepemilikan dalam bentuk yayasan pada pesantren yang ada di Kabupaten Maros lebih diwarnai dengan milik organiasasi misalnya DDI, Muhammadiyah, dan Nahdtaul Ulum. Dan sebagian merupakan yayasan milik keluarga dan milik perorangan. Adapun bentuk kepemilikan yayasan pesantren yang merupakan milik organisasi sebnayak 9 pesantren, milik keluarga 10 pesantren, dan milik perorangan sebanyak 3 pesantren.

Keberadaan pesantren di Kabupaten Maros berdasarkan letaknya dan keterjangkauannya dominan cukup terjangkau meskipun pesantren tersebut berada tidak di pusat kecamatan. Demikian juga akses menuju pesantren dominan dapat dilalui baik dengan kendaraan roda dua maupun roda empat. Lihat tabel 3.

Tabel 3. Letak dan Jarak Pesantren

\begin{tabular}{|c|c|c|c|c|c|c|c|c|c|c|c|c|c|c|}
\hline \multicolumn{3}{|c|}{ LETAK GEOGRAFIS } & \multicolumn{4}{|c|}{ JARAK PESANTREN DENGAN PUSAT DESA } & \multicolumn{4}{|c|}{$\begin{array}{l}\text { JARAK PESANTREN DENGAN PUSAT } \\
\text { KECAMATAN }\end{array}$} & \multicolumn{4}{|c|}{$\begin{array}{l}\text { JARAK PESANTREN DENGAN PUSAT } \\
\text { KABUPATEN }\end{array}$} \\
\hline $\begin{array}{c}\text { KOTA } \\
\text { KABUPATEN }\end{array}$ & $\begin{array}{c}\text { PINGGIR } \\
\text { KOTA }\end{array}$ & PEDESAAN & $\begin{array}{l}\text { DIBAWAH } 1 \\
\text { KM }\end{array}$ & 1,1 S/D $2 \mathrm{KM}$ & 2,1 S/D $3 \mathrm{KM}$ & DI ATAS 3 KM & $\begin{array}{l}\text { DIBAWAH } \\
\text { 2KM }\end{array}$ & $\begin{array}{c}2,1 \mathrm{~S} / \mathrm{D} 4 \\
\mathrm{KM}\end{array}$ & $\begin{array}{c}4,1 \mathrm{~S} / \mathrm{D} 6 \\
\mathrm{KM}\end{array}$ & $\begin{array}{l}\text { DI ATAS } 6 \\
\text { KM }\end{array}$ & $\begin{array}{c}\text { DIBAWAH } \\
5 \mathrm{KM}\end{array}$ & $\begin{array}{c}5 \mathrm{~S} / \mathrm{D} 10 \\
\mathrm{KM}\end{array}$ & $\begin{array}{c}10,1 \mathrm{~S} / \mathrm{D} 15 \\
\mathrm{KM}\end{array}$ & $\begin{array}{l}\text { DI ATAS } 15 \\
\text { KM }\end{array}$ \\
\hline $5 \%$ & $32 \%$ & $64 \%$ & $64 \%$ & $27 \%$ & $0 \%$ & $9 \%$ & 9 & 5 & 5 & 3 & 8 & 4 & 6 & 4 \\
\hline 1 & 7 & 14 & 14 & 6 & 0 & 2 & $41 \%$ & $23 \%$ & $23 \%$ & $14 \%$ & $36 \%$ & $18 \%$ & $27 \%$ & $18 \%$ \\
\hline
\end{tabular}

Secara kelembagaan pesantren di Kabupaten pendidikan diantaranya TP/TPQ, RA, MI/SD, MTs/ Maros juga menyelenggarakan berbagai jenis SMP, MA/SMA/SMK dan jenjang diniyah formal, lihat tabel 4.

Tabel 4. Jenis Pendidikan yang diselenggarakan PP

\begin{tabular}{ccccccccccc}
\hline TPQ & RA/TK & MI & MTS & MA & SD & SMP & SMA/SMK & ULA & WUSTHA & ULYA \\
4 & 11 & 12 & 21 & 19 & 5 & 6 & 4 & 5 & 2 & 2 \\
$18 \%$ & $50 \%$ & $55 \%$ & $95 \%$ & $86 \%$ & $23 \%$ & $27 \%$ & $18 \%$ & $23 \%$ & $9 \%$ & $9 \%$ \\
\hline
\end{tabular}

Pendidikan pesantren di Kabupaten Maros yang terlihat beragam merupakan akibat dinamisasi dari kemajuan zaman dewasa ini yang telah mendorong terjadinya perubahan terus-menerus tidak terkecuali lembaga pesantren, sehingga lembaga lembaga-lembaga tersebut melakukan berbagai adaptasi. Pondok pesantren kini mulai menampakan eksistensinya sebagai lembaga pendidikan Islam yang mampu bersaing. Menjawab persaingan tersebut lembaga pesantren mau tidak 
mau berusaha melengkapi diri dengan dengan berbagai jenis penyelenggaraan pendidikan formal maupun non formal.

Pesantren di Kabupaten Maros menyelenggarakan pendidikan umum baik berbentuk madrasah (sekolah umum berciri khas Islam di dalam naungan Kemenag) maupun sekolah umum (di bawah naungan Dinas) dalam berbagai jenjang pendidikan.

Ciri pondok pesantren yang dikenal dengan salafiyah kini melengkapi diri menjadi khalafiyah (modern). Perubahan ini sebagai jawaban atas tantang zaman yang diberikan pada pesantren dalam arus transformasi dan globalisasi, sehingga dalam sistem dan kultur pesantren terjadi perubahan, misalnya perubahan pengajaran dari perseorangan atau sorogan menjadi sistem klasikal yang kemudian kita kenal dengan istilah madrasah (sekolah) serta pembelajaran umum di samping masih mempertahankan pembelajaran agama (kepesantrenan).

\section{Kapasitas Pesantren di Kabupaten Maros Kiai}

Keberadaan kiai di pondok pesantren merupakan pemimpin yang sangat mewarnai corak dari pesantren dimana ia berada, dalam skala luas kiai juga memiliki peran yang sangat besar di masyarakat. Kepercayaan masyarakat terhadap kiai yang secara khusus tidak saja berurusan dengan soal keagamaan tetapi juga dalam hal sosial dan sebagainya. Kiai tidak terlepas dari budaya yang melekat terutama sebagai panutan khususnya dilingkungan dimana kiai berada. Keberadaan kiai merupakan penentu langkah berkembangan sebuah pesantren, sebagai pengasuh pesantren, ulama dan sebagai panutan masyarakat.

Untuk Kabupaten Maros beberapa sebutan digunakan bagi pimpinan pondok di antaranya kiai, anre gurutta, ustaz, dan puang. Kehadiran kiai ini bagi pondok pesantren di Kabupaten Maros mutlak ada sebagai pendukung utama dan menopang keberadaan pesantren. Dari data yang ada meskipun keberadaan kiai ini mutlak tetapi masih terdapat beberapa pesantren yang belum memiliki kiai secara tetap. Pada aspek tugas utama kiai di pondok pesantren sebagai pembina pondok, pembina pengajian kitab juga terdapat kiai yang memberikan pelajaran lain. Berdasarkan pendidikan kiai di Kabupaten Maros untuk pesantren bertipologi Khalafiyah berpendidikan S1 sebanyak 1 orang, Pesantren sebanyak 2 orang. Sedangkan latar belakang pendidikan kiai yang bertipologi pesantren kombinasi, kiai yang berpendidikan umum S3 sebanyak 2 orang, S2 sebanyak 3 orang, S1 sebanyak 5 orang, alumni pesantren sebanyak 10 orang; pendidikan agama S3 sebanyak 1 orang, S2 sebanyak 1 orang, S1 sebanyak 2 orang, SLTA sebanyak 2 orang; alumni Timur Tengah S2 sebanyak 2 orang dan S1 sebanyak 1 orang.

Latar belakang pendidikan kiai menujukkan alumni dari pesantren cukup mendominasi dari kedua tipologi pesantren, selanjutnya yang memiliki pendidikan umum juga bervariasi dari jenjang pendidikan yang ada. Latar belakang pendidikan ini oleh beberapa kiai dimiliki lebih dari satu latar belakang pendidikan, mislanya seorang kiai awalnya adalah alumni pesantren kemudian melanjutkan pendidikan ke jenjang pendidikan umum atau pendidikan agama dan sebaliknya.

Lebih lanjut untuk masing-masing kompetensi kiai di Kabupaten Maros berdasarkan tipologi pesantren yang menguasai Bahasa Arab bertipologi khalafiyah sebanyak 1 orang dan kombinasi sebanyak 15 orang, kiyai yang mempu membaca kitab kuning yang pesantren bertipologi khalafiyah sebanyak 2 orang dan 16 orang dari pesantren kombinasi. Kiai yang menghafal Alquran sebanyak 1 orang (khalafiyah) dan 8 orang (kombinasi), sedangkan yang memiliki wawasan kebangsaan sebanyak 1 orang (khalafiyah) dan 13 orang (kombinasi).

Variasi kompetensi kiai di Kabupaten Maros dari tabel menunjukkan dominasi terlihat pada kemampuan dalam membaca kitab kuning, selanjutnya kemampuan menguasai bahasa Arab, sementara kemampuan kiai dalam hal menghafal Alquran masih terbatas.

\section{Santri}

Santri (siswa) merupakan komponen pesantren yang dalam aktivitasnya adalah yang belajar mendalami ilmu agama di pesantren. Pelajaran kitab kuning atau kitab-kitab Islam klasik menjadi materi utama bagi santri di pesantren. Dalam menjalani kehidupan di pesantren, umumnya santri mengurus sendiri keperluannya. Sikap kemandirian menjadi dasar kehidupan santri di pesantren dan santri diatur sesuai dengan polapola aturan yang telah ditetapkan dan apabila santri melakukan pelanggaran akan dikenakan sanksi. Dunia santri sepenuhnya berada di pesantren selama santri tersebut masih belajar menuntut ilmu kepesantrenan. Keberdaan santri tersebut dalam hal pemondokan di pesantren beragam, ada santri 
yang mondok di pesantren dan ada pula santri yang tidak mondok yang biasa disebut dengan santri kalong. Santri yang mukim hanya sebagian di pesantren merupakan santri yang pada umumnya berasal dari jauh yang tinggal atau menetap di lingkungan pesantren dan juga terdapat santri yang berasal dari lingkungan sekitar pesantren, desa terdekat atau dengan lokasi pesantren yang mudah dijangkau oleh santri. Untuk santri yang mukin secara keseluruhan merupakan ketentuan pesantren demikian juga pesantren yang tidak memiliki santri yang bermukim/mondok. Latar belakang santri di Kabupaten Maros berasal dari orang tua yang memiliki pekerjaan dibidang pertanian. Kondisi ini memang ditunjang oleh sumber daya alam Kabupaten Maros yang memiliki lahan pertanian khususnya sawah yang cukup luas. Latar belakang pekerjaan orang tua santri sebagian kecil juga terdapat nelayan, buruh, PNS dan pekerjaan lainnya.

\section{Asrama}

Asrama (pondokan) merupakan tempat bagi santri bermukim selama ia dalam masa belajar di pesantren. Ketersediaan asrama bagi santri ini tentunya banyak menunjang segala kegiatan santri. Penggunaan asrama sebagai tempat tinggal bagi santri dan fasilitas lainnya di pesantren memiliki hak yang sama antara santri yang satu dengan lainnya. Kondisi asrama yang dimiliki pesantren di Kabupaten Maros, untuk pesantren yang bertipologi khalafiyah, khusus asrama putera sebanyak 1 asrama darurat, 1 asrama semi permanen, khusus untuk asrama puteri sebanyak 1 asrama darurat dan 1 asrama semi permanen. Kondisi asrama tipologi pesantren kombinasi khusus santri putera sebanyak 2 asrama darurat, 6 asrama semi permanen, dan 8 asrama permenen. Khusus untuk puteri (tipologi kombinasi) sebanyak 2 asrama darurat, 6 asrama semi permanen, dan 7 asrama permanen.

Asrama dengan kondisi darurat, semi permanen dan permanen ini bagi sebuah pesantren di Kabupaten Maros dominan dibangun atas dasar swadaya baik oleh pengelola pesantren maupun swadaya dari masyarakat. Meskipun terdapat beberapa pesantren yang dalam pembangunanya asrama dan beberapa fasilitas lainnya merupakan bantuan pihak terkait misalnya Kementerian Agama dan Pemerintah Daerah. Fasilitas sarana dan prasarana yang mendukung asrama santri mengalami perkembangan sedemikian rupa sehingga makin lama makin bertambah misalnya kelengkapan fasilitas tempat tidur, lemari, meja belajar, kamar mandi, dan berbagai fasilitas lainnya. Asrama yang dimiliki bagi sebagain pesantren di Kabupaten Maros pada aspek daya tampungnya juga sangat terbatas bila dibandingkan dengan jumlah santri yang ada di samping itu juga, masih terdapat pesantren yang bahkan belum memiliki asrama bagi santrinya.

\section{Masjid}

Di Kabupaten Maros komponen Masjid menjadi bagian yang tak terpisahkan dari keberadaan pesantren. Oleh kiai dan pengelola yang mendirikan sebuah pesantren pertamatama melengkapi diri dengan mendirikan masjid. Keberadaan masjid merupakan elemen yang tak dapat dipisahkan dengan pesantren dan dijadikan sebagai tempat utama untuk mendidik para santri, terutama dalam menjalankan ibadah shalat lima waktu, shalat Jumat dan sebagai tempat mempelajari kitab dan berbagai aktivitas lainnya. Seiring dengan perkembangan zaman dewasa ini pergeseran fungsi masjid sebagai salah satu tempat mempelajari kitab kini bukan hanya masjid tetapi asrama, aula, kelas juga menjadi tempat pembelajaran kitab. Sistem klasikal digunakan sebagaimana perkembangan pondok pesantren dewasa ini.

Kedudukan masjid sebagai pusat aktivitas di pesantren merupakan kesinambungan sistem pendidikan Islam yang berbasis masjid. Kondisi Masjid di lembaga-lembaga pesantren di Kabupaten Maros untuk masjid di pesantren yang bertipologi khalafiyah terdapat 2 buah masjid permanen, sedangkan kondisi masjid yang bertipologi pesantren kombinasi sebanyak 2 buah yang darurat, 1 buah masjid yang semi permanen, dan 15 buah masjid yang permanen.

Pembangunan masjid pada pondok pesantren di Kabupaten Maros terlihat dominan dibangun secara permanen dan hanya sebagian kecil pesantren yang dibangun secara semi permanen dan darurat. Dan masih terdapat dua pesantren yang belum melengkapi diri dengan fasilitas masjid. Pembangunan masjid di masing-masing pesantren di Kabupaten Maros dominan dilakukan melalui swadaya oleh pengelola pesantren dan masyarakat.

\section{Pembelajaran Kitab}

Pembelajaran kitab di pesantren merupakan cirri khas yang melekat pada pondok pesantren, model dalam pembelajaran ini diberikan di luar jam-jam sekolah sehingga dapat diikuti oleh semua santrinya. Pembelajaran kitab ini dominan 
diterapkan pondok pesantren di Kabupaten Maros.

Intensitas pembelajaran kitab yang dilakukan pada masing-masing pesantren di Kabupaten Maros sangat bervariasi mulai dari pembelajaran kitab setiap hari (tiga kali), seminggu (satu kali sampai empat kali), dan sebulan (satu sampai tiga kali). Pembelajaran kitab dominan dilakukan di masjid selain itu juga dilakukan di kelas, di asrama, dan di aula. Waktu pembelajaran dilakukan ba'da shalat magrib dan shalat subuh. dalam pendidikan pesantren di Kabupaten Maros adalah metode kepesantren pada umumnya misalnya wetonan, sorogan, dan hafalan. Metode wetonan merupakan metode pembelajaran dimana
Metode pembelajaran yang lazim digunakan

para santri mengikuti pelajaran dengan duduk disekeliling kiai yang memberi pelajaran. Santri menyimak pelajaran kitab dan mencatat jika perlu. Metode sorogan santri menghadap guru satu-persatu dengan membawa kitab yang ingin dipelajari. Kiai membacakan, menerjemahkan dan menerangkan isi dari kitab yang dipelajari.

Metode hafalan, yakni santri menghafal isi dari kitab yang dipelajarinya. Materi hafalan biasanya dalam bentuk syair atau nazham. Sebagai pelengkap metode hafalan sangat efektif untuk memelihara daya ingat santri terhadap materi yang dipelajarinya, karena dapat dilakukan baik di dalan maupun di luar kelas. Metode hafalan juga digunakan untuk menghafal Alquran sesuai dengan ketentuan pesantren. Beberapa kitab yang dimiliki pesantren di Kabupaten Maros lihat tabel 5.

Tabel 5.

Jumlah Kepemilikan Kitab

Berdasarkan Tipologi PP

\begin{tabular}{|c|c|c|c|c|c|}
\hline \multirow{2}{*}{ NO } & \multirow{2}{*}{ URAIAN } & \multicolumn{3}{|c|}{ TIPOLOGI PESANTREN } & \multirow{2}{*}{ JUMLAH } \\
\hline & & SALAFIYAH & KHALAFIYAH & KOMBINASI & \\
\hline 1 & PEMBELAJARAN KITAB & 0 & 2 & 18 & 20 \\
\hline \multirow[t]{17}{*}{2} & JENIS KITAB & & & & \\
\hline & HADIS & 0 & 0 & 16 & 16 \\
\hline & TAJWID & 0 & 0 & 2 & 2 \\
\hline & IMLAK & 0 & 0 & 1 & 1 \\
\hline & AKHLAK & 0 & 1 & 3 & 4 \\
\hline & SHARAF & 0 & 1 & 4 & 5 \\
\hline & BAHASA ARAB & 0 & 0 & 3 & 3 \\
\hline & FIQHI & 0 & 1 & 16 & 17 \\
\hline & TAUHID & 0 & 0 & 2 & 2 \\
\hline & TAFSIR & 0 & 1 & 16 & 17 \\
\hline & ULUMUL QURAN & 0 & 0 & 0 & 0 \\
\hline & ULUMUL HADIS & 0 & 0 & 2 & 2 \\
\hline & ULUMUL FIQHI & 0 & 0 & 1 & 1 \\
\hline & MANTIQ & 0 & 0 & 1 & 1 \\
\hline & TARIKH & 0 & 0 & 3 & 3 \\
\hline & BALAGHAH & 0 & 0 & 1 & 1 \\
\hline & ARUDH & 0 & 0 & 0 & 0 \\
\hline
\end{tabular}

Berdasarkan tabel di atas pembelajaran kitab yang dilakukan masih terdapat pondok pesantren yang belum melakukan pembelajaran kitab secara khusus. Dari 22 pondok pesantren terdapat 2 pesantren yang melakukan pembelajaran kitabnya hanya mengintegrasikannya ke dalam mata pelajaran yang diajarkan di kelas. Dari tabel kepemilikian kitab tersebut ketersediaannya pada pondok pesantren dapat dikatakan sangat minim jika didasarkan pada standar kitab yang ditetapkan oleh Kementerian Agama.

\section{Pemberdayaan Pesantren di Kabupaten Maros}

Bertambahnya komponen pendidikan pondok pesantren, misalnya dengan berbagai pemberdayaan yang bertujuan untuk menambah keterampilan santri sesuai dengan kemampuan dan kebutuhan santri dan masyarakat. Relevasi pemberdayaan bagi santri dengan kehidupannya akan lebih bermakna bagi santri. Realitas kehidupan santri adalah perubahan dan sebuah perubahan menuntut adanya kemampuan untuk menghadapinya. 
Tujuan pemberdayaan di pondok pesantren adalah untuk menfungsikan pendidikan yang sesungguhnya, yaitu untuk mengembangkan santri menghadapi perannya di masyarakat dan dapat mengaktualisasikan kemampuan santri secara mandiri serta mengoptimalkan sumberdaya lingkungan pesantren sesuai dengan program pondok pesantren. Berbagai pemberdayaan pemberdayaan yang di programkan pondok pesantren di kabupaten Maros berdasarkan tipologinya. Pesantren bertipologi khalafiyah: 2 pesantren yang melakukan pemberdayaan dibidang peternakan, 1 pesantren yang menyelenggarakan pemberdayaan dibidang keterampilan, dan 1 pesantren yang melakukan pemberdayaan di bidang ekonomi. Untuk pesantren yang bertipologi kombinasi: 6 pesantren yang melakukan pemberdayaan dibidang pertanian, 5 pesantren yang melakukan pemberdayaan dibidang peternakan, 7 pesantren yang melakukan pemberdayaan dibidang keterampilan, dan 4 pesantren yang melakukan pemberdayaan di bidang ekonomi.

Tabel 6 Kondisi dan Pengelola Pemberdayaan

$\begin{array}{cc}\text { NO } & \text { PESANTREN } \\ 1 & \text { PP. Darul Istiqamah Maccopa } \\ 2 & \text { PP. An Nas Az Zahrah } \\ 3 & \text { PP. Darussalam Barandasi } \\ 4 & \text { PP. DDI Soreang } \\ 5 & \text { PP. Nahdlatul Ulum Soreang } \\ 6 & \text { PP.Yadi Bontocina } \\ 7 & \text { PP. Darul Muttaqin Maccopa } \\ 8 & \text { PP. Manbaul Ulum Firdaus } \\ & \text { Tompobalang } \\ 9 & \text { PP. Darul Ulum Amessangeng } \\ 10 & \text { PP. Miftahu Muin Tekolabbua } \\ 11 & \text { PP. Ainussyamsi } \\ 12 & \text { PP. Profesi Wandaniyatillah } \\ 13 & \text { PP. Babul Jannah } \\ 14 & \text { PP. Nurul Ikhwan Matana } \\ & \\ 15 & \text { PP. Raudhaturrasyidin } \\ & \end{array}$

\section{PERMBERDAYAAN}

Ikan, Peternakan

Kantin sekolah

Keterampilan, sablon, menjahit

Keterampilan menjahit

Mini Market, koperasi

Pertanian (padi), peternakan sapi, koperasi

Ket. Menjahit dan Otomotif

Padi, pala wija, dan holtikultura.

Sapid an puyuh. Tatarias dan menjahit, koperasi dan kantin

Peternakan sapi
Peternakan, susu kedelai
Peternakan, ket.menjahit
Pertanian cabe dan pertukangan
meubel
Pertanian padi, tambak ikan
Perkebunan Mangga, Ket.
Menjahit, tat arias, dan
membuat atap rumbia

\section{KONDISI \\ Mandeq \\ Mandeq}

Berlanjut

Berlanjut

Berlanjut

Mandeq

Berlanjut

Mandeq

Mandeq

Mandeq

Mandeq

Mandeq

Berlanjut

Berlanjut

Berlanjut
PENGELOLA

Santri dan staf

Santri, staf, dan masy

Santri, staf, dan masy

Santri dan staf

Staf

Santri, staf, dan masy

Santri, staf, dan masy

Santri, staf, dan masy

Staf

Staf dan santri

Santri, staf, dan masy

Santri, staf, dan masy

Santri, staf, dan masy

Santri dan Staf

Santri dan Staf

Santri, staf, dan masy
Berberbagai bidang pemberdayaan telah diprogramkan oleh masing-masing pesantren baik bidang pertanian, peternakan, keterampilan dan ekonomi. Dari jumlah pesantren yang telah melakukan pemberdayaan tersebut meskipun sebagianya sudah tidak berlanjut setidaknya sudah melakukan pemberdayaan meskipun mandeq. Tuntutan manajemen pemberdayaan yang professional dengan perencanaan, proses serta kesinambungan pemberdayaan menjadi penting untuk ditindaki. Mempertimbangkan pentingnya pengembangan pemberdayaan sebagai bekal keterampilan bagi santri bersangkutan. Program pemberdayaan tersebut dikelola oleh santri pesantren, staf pesantren dan terdapat juga pemberdayaan yang dikelola oleh masyarakat.

Pesantren yang tidak memprogramkan pemberdayaan bagi santrinya bukan berarti tidak membekali santrinya dengan berbagai program soft skill (seperti kegiatan ekstrakurikuler pramuka, seni, bela diri, olah raga, dakwah dan berbagai keterampilan lain).

\section{PENUTUP}

Persebaran pesantren di Kabupaten Maros secara riil yang berjumlah 22 pesantren belum 
menjangkau setiap kecamatan yang mayoritas penduduknya beragama Islam. Sebagai wujud pemeratan pendidikan dan akses pendidikan agama dan keagamaan bagi masyarakat persebarannya belum terlihat berimbang di Kabupaten Maros.

Pesantren di Kabupaten Maros, terlihat pada lima komponen yang harus dipenuhi oleh pesantren, pada kenyataannya bahwa pesantren belum semuanya memenuhi lima komponen dimaksud, pada hal lima komponen pesantren seperti ketersediaan kiai, asrama, masjid, dan pembelajaran kitab itu menjadi pintu masuk bagi Kementerian Agama untuk memberikan penguatan terhadap pesantren.

Peran pesantren diharapkan juga mampu mengembangkan kemadirian santri memalui pemberdayaan berupa keterampilan sebagai bekal dalam melakukan pengembangan di masyarakat. Pemberdayaan tersebut belum memberikan hasil yang optimal terlihat dari keberlanjutan dan pengelolaan yang belum termenej dengan baik.

\section{UCAPAN TERIMA KASIH}

Tulisan ini hadir tidak terlepas dari bantuan berbagai pihak, ucapan terimakasi penulis haturkan kepada Kepala Balai Penelitian dan Pengembangan Agama yang telah menugaskan peneliti di Kabupaten Maros. Kepala Kemenag Kabupaten Maros beserta jajaran, dan kepada bapak dan ibu pengelola Pondok Pesantren di Kabupaten Maros yang tidak dapat penulis sebutkan satu persatu, atas bantuannya dan partisipasinya kepada peneliti dalam pengumpulan data lapangan. Dan kepada rekan-rekan peneliti yang telah memberikan sumbang saran, kritik dan masukannya untuk melengkapi tulisan ini. Kepada tim redaksi atas termuatnya tulisan ini penulis haturkan terimkasih banyak.

\section{DAFTAR PUSTAKA}

Badan Litbang dan Diklat Kemenag, 2012. Dinamika Pendidikan Pesantren di Indonesia. Jakarta. Puslitbang Pendidikan Agama dan Keagamaan.

Bawani, Imam, dkk. 2011. Pesantren Buruh Pabrik, Pemberdayaan Buruh Pabrik Berbasis Pendidikan Pesantren. Yogyakarta: LKiS.

Departemen Pendidikan Nasional. 2005. Kamus Besar Bahasa Indonesia. Jakarta: Balai Pustaka.

Echols, John M dan Hasan Shadily. 2000. Kamus Inggris Indonesia. Jakarta: Gramedia.

Madjid, Nurcholish. tth. Bilik-bilik Pesantren. Jakarta: Paramadina.

Nasir, Ridlwan. 2010. Mencari Tipologi Format Pendidikan Ideal: Pondok Pesantren Di Tengah Arus Perubahan. Cet II. Yogyakarta: Pustaka Pelajar.

Noor, Mahpudin. 2006. Potret Dunia Pesantren: Lintas Sejarah, Perubahan, dan Perkembangan Pondok Pesantren. Bandung: Humaniora.

Octavia, Lanny. dkk. 2014. Pendidikan Karakter Berbasis Tradisi Pesantren. Jakarta: Rumah Kitab.

Qomar, Mujamil. tth. Pesantren Dari Transformasi Metodologi Menuju Demokrasi Institusi. Jakarta: Erlangga.

Sugiono. 2005. Memahami Penelitian Kualitatif. Bandung: Alfabeta.

Suhardi, Didik, 2012. Peran SMP Berbasis Pesantren Sebagai Upaya Penanaman Pendidikan Karakter Kepada Generasi Muda. Journal Pendidikan Karakter. Tahun II, Nomor 3 Oktober 2012.

Tafsir, Ahmad. 2013. Ilmu Pendidikan Islam. Bandung: PT. Remaja Rosdakarya.

www.nu.online.go.org, diakses 12 Januari 2015.

Zakaria, Gamal Abd. Nasir. 2010. Pondok Pesantren: Change and Its Future. Journal of Islamic and Arabic Education 2 (2) Hal. 45-52. 